TITLE:

\title{
ELEVEN NEW BIVALVES FROM TANABE BAY, WAKAYAMA PREF., JAPAN
}

AUTHOR(S):

Habe, Tadashige

CITATION:

Habe, Tadashige. ELEVEN NEW BIVALVES FROM TANABE BAY, WAKAYAMA PREF., JAPAN. PUBLICATIONS OF THE SETO MARINE BIOLOGICAL LABORATORY 1960, 8(2): 281-288

ISSUE DATE:

1960-12-20

URL:

http://hdl.handle.net/2433/174652

RIGHT: 


\title{
ELEVEN NEW BIVALVES FROM TANABE BAY, WAKAYAMA PREF., JAPAN ${ }^{1,2)}$
}

\author{
Tadashige HABE \\ Amäkusa Marine Biological' Laboratory \\ (Kyushu University), Reihoku-cho, Amakusa \\ With 24 Text-figures
}

During the biological survey of Tanabe Bay which was carried out on 8th and 9th of September, 1958, 195 species of bivalves have been collected, of which 11 species are new to science. Therefore the writer describes them herein. The type specimens of these new species are deposited in the Amakusa Marine Biological Laboratory.

Before going further the writer wishes to express his sincere thanks to the members of the Seto Marine Biological Laboratory for their cooperations and Dr. T. Kuroda, Dr. K. Sakurai and Mr. Y. Matsumoto for their warm-hearted advices.

1. Mantellum amakusaense sp. nov. (Limidae)

Shell thin, translucent, milky white, inflated, ovate, oblique to the anterior side. Valves closing tightly without a gape. Anterior margin nearly straight and the posterior curved outwards. Surface with many fine radial riblets which are crossed by the lines of growth forming a reticulation. Umbo moderately projecting above the hinge which is straight. Hinge plate with a broad triangular ligamental area extending to the small auricles at anterior and posterior sides. Margin denticulated corresponding with the radial threads.

Length $7.7 \mathrm{~mm}$, height $11.7 \mathrm{~mm}$ and breadth $3.5 \mathrm{~mm}$ (left valve) (Type specimen)

Length $5.6 \mathrm{~mm}$, height $9.0 \mathrm{~mm}$ and breadth $2.5 \mathrm{~mm}$ (left valve) (Paratype specimen) .

Length $5.3 \mathrm{~mm}$, height $8.2 \mathrm{~mm}$ and breadth $2.4 \mathrm{~mm}$ (right valve) (Paratype specimen)

1) Contributions from the Amakusa Marine Biological Laboratory, No. 136.

2) Contributions from the Seto Marine Biological Laboratory, No. 354.

Publ. Seto Mar. Biol. Lab., VIII (2), 1960. (Article 19) 
Type locality: Tomioka, Amakusa, Kyushu.

Distribution: Tanabe Bay, Wakayama Pref., Honshu.

Remarks: This is rather common at Tomioka and is easily distinguished from allied forms, $M$. orientale (A. Adams et REEvE 1850) and $M$. hakodatense (TokunagA 1906 ) in having the very inflated shell without a gap at the posterior end.

\section{Limatula nippona sp. nov. (Limidae)}

Shell small, rather thin, white, ovate, equilateral, swollen, Valves closed without a gape. Hinge plate with a broad triangular ligamental area. Hinge straight and edentulous, auriculate at both anterior and posterior ends. Sculpture with many angulate and distantly placed radial ribs which become weaker and narrower towards anterior and posterior sides. Middle groove distictly marked. Umbo small, but projected beyond the hinge line. The interior of shell with a distinct middle groove between two stout radial ribs.

Type locality: Tanabe Bay, Wakayama Pref.

Length $4.0 \mathrm{~mm}$, height $5.6 \mathrm{~mm}$ and breadth $1.9 \mathrm{~mm}$ (right valve) (Type specimen)

Length $4.0 \mathrm{~mm}$, height $5.6 \mathrm{~mm}$ and breadth $1.9 \mathrm{~mm}$ (right valve) (Paratype specimen)

Distribution: Katsuura Bay, Wakayama Pref. and Tomioka, Amakusa.

Remarks: This new species closely relates to the young shell of Limatula japonica (A. ADAMS 1863) but is easily distinguished from that species in having the shell with a distinct middle groove and more numerous narrow radial ribs. L. kurodai Oxama 1943 is another ally. This is a quite thin shell the radial ribs on which are very weak and reduce away at both anterior and posterior areas. Limatula strangei (SoWERBY 1872) and L. vladivostokensis SCALATO 1955 have a more elongate shells than this new species.

\section{Pillucina neglecta sp. nov. (Lucinidae)}

(Figs. 7, 8 et 9 )

Shell small, white, solid, orbicular, produced anteriorly and strongly swollen. Surface with concentric lamellate growth lines which become strong at the posterior area and with divaricate ribs except the middle area. Lunule smooth, excavate and distinctly impressed. Umbo oblique anteriorly. Left valve has two solid cardinal teeth which are divaricating and a big pit and a groove for the reception of the lateral teeth in the right valve which has a very solid cardinal tooth and a knob-like anterior lateral tooth far apart from the cardinal and a long posterior lateral. The interior of ventral margin strongly crenulated corre- 
sponding with the radial sculpture on the surface.

Length $2.2 \mathrm{~mm}$, height $2.3 \mathrm{~mm}$ and breadth $1.5 \mathrm{~mm}$ (conjoined valves) (Type specimen)

. Length $2.2 \mathrm{~mm}$, height $2.1 \mathrm{~mm}$ and breadth $1.5 \mathrm{~mm}$ (conjoined valves) (Paratype specimen)

Length $2.4 \mathrm{~mm}$, height $2.5 \mathrm{~mm}$ and breadth $1.0 \mathrm{~mm}$ (right valve) (Paratype specimen figured)

Type locality: Tanabe Bay, Wakayama Pref.

Distribution: Nanao Bay, Ishikawa Pref., Obama Bay, Fukui Pref., Bingo Nada, a central part of the Inland sea of Japan and Ago Bay, Mie Pref.

Remarks: This has been confused with Pillucina pisidium (DUNKer 1860) which dwells commonly in the intertidal and subtidal zones in bays, until today. But the shell of the former is smaller in size even in the adult stage, more solid and more swollen than the latter. This is commonly collected from fine sandy mud in the middle area of this bay.

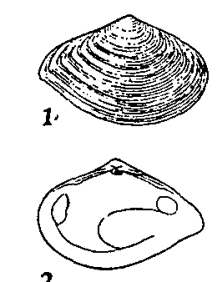

2
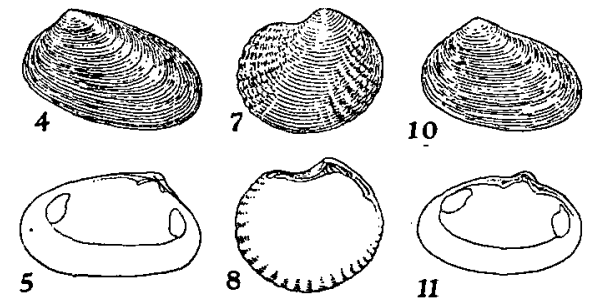

11
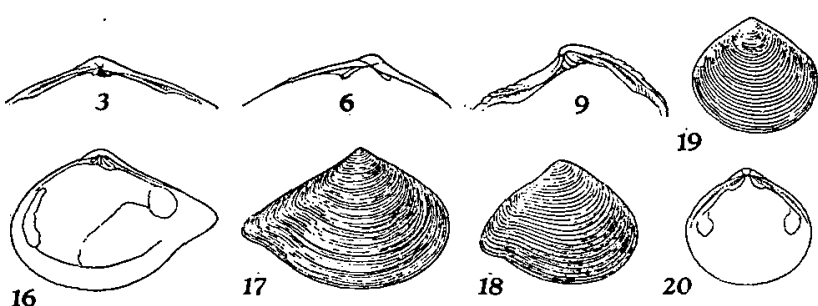

19

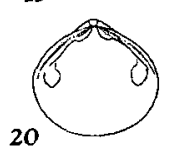

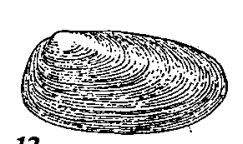
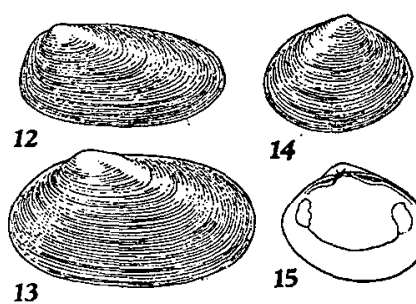

14
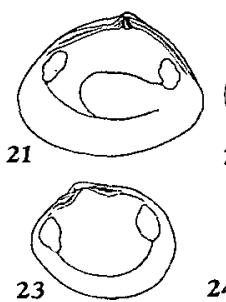

22

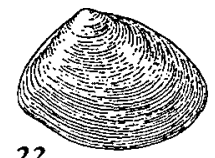

24

Figs. 1-3. Leptomya minuta sp. nov. from Tanabe Bay $(\times 5)$, 4-6. Nipponomysella obesa sp. nov. from Tanabe Bay $(\times 5)$, 7-9. Pillucina neglecta sp. nov. from Tanabe Bay $(\times 5), 10,11$. Nipponomysella tanabensis sp. nov. from Tanabe Bay $(\times 4), 12$. Nipponomysella oblongata (Yokoyama) from Mutsu Bay, Aomori Pref. (2.5), 13. Fronsella fujitaniana (YoKoy AMA) from Mutsu Bay, Aomori Pref., ( $\times 3$ ), 14, 15, Kellia minutissima sp. nov. from Tanabe Bay $(\times 5)$, 16, 17. Leptomya cuspidariaeformis Habe from Sagami Bay, Kanagawa Pref. $(\times 1.5)$, 18. Plectodon (Pseudoneaera) tanabensis sp. nov. from Tanabe Bay $(\times 4), 19,20$. Montacutona crassa (Yokoy AmA) from Tanabe Bay $(\times 4)$, 21, 22. Leptomyaria trigona gen. et sp. nov. from Tomioka, Amakusa $(\times 4), 23,24$. Kellia minutissima sp. nov. from Tanabe Bay $(\times 5)$.

\section{Kellia minutissima sp. nov. (Erycinidae)}

(Figs. 14, 15, 23 et 24 )

Shell minute, thin, white to light brown, orbicular to rounded ovate, rounded 
posteriorly and slightly attenuated anteriorly, inflated. Umbo inclined forwards and situated at one-third from the anterior end. Surface smooth, with growth lines only. In the right valve two diverging cardinal teeth, and a resilium present between them. In the left valve a small cardinal tooth below the umbo and the anterior lateral tooth strong, forming a deep groove along the antero-dorsal margin, and the posterior lateral tooth obscure. Pallial line simple.

Length $2.9 \mathrm{~mm}$, height $2.5 \mathrm{~mm}$ and breadth $1.0 \mathrm{~mm}$ (right valve) (Type specimen figured)

Length $2.6 \mathrm{~mm}$, height $2.2 \mathrm{~mm}$ and breadth $0.8 \mathrm{~mm}$ (left valve) (Paratype specimen)

Length $2.4 \mathrm{~mm}$, height $2.0 \mathrm{~mm}$ and breadth $0.8 \mathrm{~mm}$ (right valve) (Paratype specimen figured)

Type locality: Tanabe Bay, Wakayama Pref.

Remarks: This is very common in this bay and is the smallest species of this genus hitherto found in Japan.

\section{Mysella tanabensis sp. nov. (Montacutidae)}

Shell small, moderately thick, light yellowish white, subtrigonal, compressed. inaequilateral, with larger posterior area than the anterior. Surface with growth lines only. Umbo small and oblique forwards. In the right valve two cardinal teeth and a small resilifer pit below the umbo. Pallial sinus entire, without a posterior sinuation.

Length $4.5 \mathrm{~mm}$, height $3.5 \mathrm{~mm}$ and breadth $0.5 \mathrm{~mm}$ (right valve) (Type speci men)

Type locality: Tanabe Bay, Wakayama Pref.

Distribution: Tomioka, Amakusa.

Remarks: Though only two valves have been collected from these two localities, the writer has named this for the reason of the first species of this genus from Japan.

\section{Nipponomysella tanabensis sp. nov. (Montacutidae)}

(Figs. 10 et 11)

This species closely resembles Fronsella fujitaniana (Yokoy AmA) (Fig. 13) in shape, but the hinge teeth, of this species is quite different in having the two diverging cardinal teeth in the left valve, while the right valve without any teeth. Shell small, rather thin, white, smooth and polished, elongate oval in shape, subtruncated anteriorly and elongated and slightly narrowed to the round posterior end. 
Length $3.9 \mathrm{~mm}$, height $2.5 \mathrm{~mm}$ and breadth $0.8 \mathrm{~mm}$ (left valve) (Type specimen figured)

Length $3.7 \mathrm{~mm}$, height $2.3 \mathrm{~mm}$ and breadth $0.7 \mathrm{~mm}$ (right valve) (Paratype specimen)

Length $6.1 \mathrm{~mm}$, height $3.8 \mathrm{~mm}$ and breadth $1.0 \mathrm{~mm}$ (left valve) (Paratype specimen from Tomioka, Amakusa)

Length $5.5 \mathrm{~mm}$, height $3.6 \mathrm{~mm}$ and breadth $1.1 \mathrm{~mm}$ (right valve) (Paratype specimen from Tomioka, Amakusa)

Type locality: Tanabe Bay, Wakayama Pref.

Distribution: Tomioka, Amakusa; Ushimado, Okayama Pref. and Oura, near Asamushi, Aomori Pref.

Remarks: Nipponomysella oblongata (Yoкоyama 1922) (Fig. 12) also differs from this new species in having the elongate shell, the dorsal and ventral margins of which are paralell and with a distinct sinuation in front of the umbo. Nipponomysella subtruncata (YoKоYAMA 1927) is also very similar to this species in having the subtruncated frontal margin of shell, but that species has a much smaller and transversely elliptical shell. This was erroneously listed by the writer (1960) as Fronsella tanabensis in his paper "Pelecypod shell remains in Tanabe Bay, Wakayama Prefecture".

\section{Nipponomysella obesa sp. nov. (Montacutidae)}

(Figs. 4, 5 et 6 )

Shell small, thin, white, obliquely oblong ovate, rounded at both anterior and posterior ends and strongly produced at the posterior side nearly twice as long as the anterior, inflated. Surface smooth and polished, sometimes showing the resting undulations. Umbo small, inclined forwards. Left valve with two thin diverging cardinal teeth the posterior of which is longer than the anterior and with no lateral tooth. Right valve with no teeth, but with the extension of the dorsal margin to be fixed grooves between the cardinal teeth and anterior and posterior dorsal margins in the left valve.

Length $3.7 \mathrm{~mm}$, height $2.1 \mathrm{~mm}$ and breadth $0.8 \mathrm{~mm}$ (left valve) (Type specimen figured)

Length $3.5 \mathrm{~mm}$, height $2.2 \mathrm{~mm}$ and breadth $0.8 \mathrm{~mm}$ (right valve) (Paratype specimen)

Length $3.5 \mathrm{~mm}$, height $2.2 \mathrm{~mm}$ and breadth $0.7 \mathrm{~mm}$ (right valve) (Paratype specimen)

Type locality: Tanabe Bay, Wakayama Pref.

Remarks: This is very characteristic of the inflated fragile shell quite differing from the allied species, N. oblongata (Yokoyama 1922), N. tanabensis HABE and N. subtruncata (YoKoy Ama 1927), which have the rather, thick compressed shell. 
Montacutona crassa (YoKoYAma 1927) (Figs. 19, 20) was also found in this bay.

\section{Dorisca (Crenocirce subgen. nov.) picta sp. nov. (Veneridae)}

Shell small, solid, somewhat compressed, white to yellow usually with brown broches in the posterior area, ovate, rounded anteriorly and subtruncated posteriorly. Surface with divericating radial ribs which meet each other in the median area and which are crossed with the ribs of growth. Three diverging cardinal teeth below the umbo in each valve. A deep socket of the right valve corresponding with a knob-like anterior lateral tooth of the left valve. No posterior lateral tooth in each valve. Pallial sinus present very shallowly at the posterior part of pallial line. Internal margin minutely crenulated.

Length $5.8 \mathrm{~mm}$, height $5.4 \mathrm{~mm}$ and breadth $1.5 \mathrm{~mm}$ (left valve) (Type specimen)

Length $4.6 \mathrm{~mm}$, height $4.0 \mathrm{~mm}$ and breadth $2.7 \mathrm{~mm}$ (Conjoined valves) (Paratype specimen)

Length $4.6 \mathrm{~mm}$, height $4.2 \mathrm{~mm}$ and breadth $2.5 \mathrm{~mm}$ (Conjoined valves) (Paratype specimen)

Type locality: Amami-Oshima, Kagoshima Pref.

Distribution: Tanabe Bay and Shionomisaki, Wakayama Pref.

Remarks: This subgenus is very close to the genus Dorisca Dall, Bartsch and REHDER 1939 from Hawaii, but is easily distinuished from the latter in having the crenulation on the interior of ventral margin.

\section{Leptomya minuta sp. nov. (Semelidae)}

(Figs. 1, 2 et 3 )

Shell minute, fragile, white in dead specimens and semitranslucent and polished in living specimens, moderately convex, ovate in outline, moderately produced anteriorly and cuspidated posteriorly. Ventral margin gently curved and with a slight concavity near the posterior end. Umbo small but erect, nearly centrally placed. Surface smooth, with weak growth lines and faint radial threads. An obtuse flexure from the umbo to the posterior rostration. Two small cardinal teeth and a distinct resilifer pit between them below the umbo in right valve. Anterior and posterior lateral teeth very long, forming a groove along each dorsal margin, anterior and posterior, apart from the cardinal teeth. In the left valve only two cardinal teeth with a resilifer pit between them and no lateral teeth. Pallial sinus deep, extending to the half way of the pallial line.

Length $3.7 \mathrm{~mm}$, height $2.7 \mathrm{~mm}$ and breadth $1.0 \mathrm{~mm}$ (right valve) (Type specimen figured) 
Length $3.5 \mathrm{~mm}$, height $2.5 \mathrm{~mm}$ and breadth $0.8 \mathrm{~mm}$ (right valve) (Paratype specimen)

Length $3.1 \mathrm{~mm}$, height $2.1 \mathrm{~mm}$ and breadth $0.6 \mathrm{~mm}$ (left valve) (Paratype specimen)

Type locality: Tanabe Bay, Wakayama Pref.

Distribution: Yura Bay, Wakayama Pref. and Bingo Nada, a central part of the Inland Sea of Japan.

Remarks: This species resembles a young shell of Leptomya cuspidariaeformis HABE 1952 in shape, but the shell of the former species is quite small even in the adult form and has long lateral teeth in the right valve.

\section{Leptomyaria trigona gen. et sp. nov. (Semelidae)}

(Figs. 21 et 22)

Shell small, white and polished, solid, rather compressed, trigonal ovate in shape. Surface with only weak growth lines and covered with pale yellowish periostracum and has an obtuse flexure from the umbo to the posterior end. Anterior dorsal margin convex and the posterior dorsal nearly straight and ventral margin gently curved. Cardinal plate solid and broad. Right valve with two solid but small cardinal teeth and a narrow oblique resilifer pit between them and a long anterior and posterior lateral teeth forming deep gooves along the dorsal margin. Left valve with two cardinal teeth and no lateral teeth. Pallial sinus deeply extending to near the anterior scar.

Length $5.0 \mathrm{~mm}$, height $4.4 \mathrm{~mm}$ and breadth $2.4 \mathrm{~mm}$ (conjoined valves) (Type specimen)

Length $4.7 \mathrm{~mm}$, height $4.0 \mathrm{~mm}$ and breadth $2.3 \mathrm{~mm}$ (conjoined valves) (Paratype specimen)

Length $4.4 \mathrm{~mm}$, height $3.8 \mathrm{~mm}$ and breadth $1.8 \mathrm{~mm}$ (conjoined valves) (Paratype specimen)

Length $4.9 \mathrm{~mm}$, height $4.3 \mathrm{~mm}$ and breadth $1.2 \mathrm{~mm}$ (right valve) (Paratype specimen)

Type locality: Tomioka, Amakusa.

Distribution: Tanabe Bay, Wakayama Pref.

Remarks: This new species differs from the species of the genus Leptomya in having the solid shell which is not rostrated posteriorly and widely produced anteriorly, giving triangular in outline and with the long anterior and posterior lateral teeth on the broad thick hinge plate. Therefore, a new generic name is proposed for this interesting species, as the type species. 
11. Plectodon (Pseudoneaera) tanabensis sp. nov. (Cuspidariidae)

(Fig. 18)

Shell small, rather thin, inflated, white, covered with a light yellowish periostracum, subtriangular in shape, rounded anteriorly and rostrated posteriorly. Surface with distantly placed concentric lamellae and a flexure from the umbo to the posterior end. Therefore the ventral margin with a concavity in front of the flexure. Right valve with two cardinal teeth, the posterior one is very solid as a knob and the anterior rather weak. Left valve with no teeth, but with a small resilifer pit.

Length $4.7 \mathrm{~mm}$, height $3.7 \mathrm{~mm}$ and breadth $1.5 \mathrm{~mm}$ (right valve) (Type specimen)

Length $6.0 \mathrm{~mm}$, height $4.8 \mathrm{~mm}$ and breadth $2.0 \mathrm{~mm}$ (right valve) (Paratype specimen from Tomioka, Amakusa).

Type locality: Tanabe Bay, Wakayama Pref.

Distribution: Tomioka, Amakusa.

Remarks: The shell of this new species resembles those of Plectodon (Pseudoneaera) iridella Kuroda 1948 and Pl. (Ps.) subpellucida Kuroda 1948 in shape, but may be easily distinguished from them in having the distantly placed undulation on the surface.

\section{REFERENCES}

Dall, Bartsch and Rehder 1939. Bernice P. Bishop Mus., Bull. 153, pp. 1-233.

HABE, T. 1951-52. Genera Jap. Shells, 1-3, 1-278.

1960. Rec. Oceanogr. Works Japan, Sp. No. 4, 39-51.

Kuroda, T. 1948. Venus (Jap. Jour. Malac.), 15, 1-28.

LAseron, Ch. 1956. Rec. Austr. Mus., 24 (2), 7-21.

OyamA, K. 1943. Conch. Asiatica, 1, 1-74.

PALMER, K. V. W. 1950. Jour. de Conchyl,, 90, 193-194.

Scalato, O. A. 1955. Atlas Invert. Far East Seas USSR, 167-202.

Yokoy AmA, M. 1922. Jour. Coll. Sci. Imp. Univ. Tokyo, 44 (1), 157.

1927. Jour. Fac. Sci. Imp. Univ. Tokyo, (2) 1 (10), 431-433. 